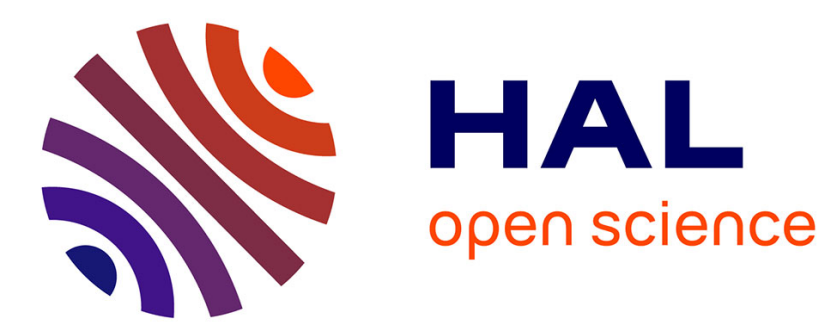

\title{
A differential photoacoustic imaging system
}

\author{
C. Hall, A. Williams, N. Wood
}

\section{To cite this version:}

C. Hall, A. Williams, N. Wood. A differential photoacoustic imaging system. Journal de Physique IV Proceedings, 1994, 04 (C7), pp.C7-43-C7-46. 10.1051/jp4:1994711 . jpa-00253162

\section{HAL Id: jpa-00253162 https://hal.science/jpa-00253162}

Submitted on 1 Jan 1994

HAL is a multi-disciplinary open access archive for the deposit and dissemination of scientific research documents, whether they are published or not. The documents may come from teaching and research institutions in France or abroad, or from public or private research centers.
L'archive ouverte pluridisciplinaire HAL, est destinée au dépôt et à la diffusion de documents scientifiques de niveau recherche, publiés ou non, émanant des établissements d'enseignement et de recherche français ou étrangers, des laboratoires publics ou privés. 


\title{
A differential photoacoustic imaging system
}

\author{
C.A. Hall, A.W. Williams and N.J. Wood $(1)$ \\ Department of Physics, University College Swansea, University of Wales, Singleton Park, \\ Swansea SA2 8PP, U.K.
}

\begin{abstract}
We describe a differential photoacoustic (PA) imaging system in which almost equal intensity beams modulated $180^{\circ}$ out of phase illuminate two regions of a sample in a PA cell. For two regions that are both optically and thermally similar and also homogeneous, the resulting signal is almost zero but if one region has a sub-surface defect this will give an increased signal. This differential signal has a much higher signal to noise ratio than conventional PA systems.
\end{abstract}

\section{NTRODUCTION}

Scanning photoacoustic microscopy or SPAM [1] has been used for several years in the field of non-destructive evaluation detecting voids [2], inclusions [3], cracks [4] and also in measurements of coating thickness [5] for a variety of electrically conductive and insulating materials. A conventional SPAM system uses a single localised heat source, often produced by a laser focused onto a small area of the sample surface. Intensity modulation of the laser beam periodically heats the sample surface and assuming the optical absorption length at the laser wavelength is very short compared with the sample thickness, the sample can be probed to a depth given by the thermal diffusion length; $\mu_{s}=\sqrt{\alpha_{s} / \pi f}$ where $\alpha_{s}$ is the thermal diffusivity and $f$ the modulation frequency. Such depth profiling gives information about the thermal properties of the sample in the direction perpendicular to the surface. If signals are obtained at different points on the sample surface both surface and subsurface features in the material may be detected.

Methods of improving the signal/noise ratio in photothermal scanning experiments have been discussed previously. Busse and Ograbeck [6] used an oscillating mirror to position modulate a laser pump beam in the same direction as a linear scan to give a difference signal. Position modulation was also used by Quimby [7] who modulated a pump beam by reflection from the vibrating cone of a microphone. An oscillating mirror that moved a laser beam across two sample plates was employed by Lehto et al [8]. In this experiment an infra-red detector produced differential signal. In the present system the laser beam is split into two beams that are chopped $180^{\circ}$ out of phase and are incident on a sample in a PA cell. For a homogeneous sample the beams will produce photoacoustic signals that are equal in magnitude but $180^{\circ}$ out of phase. If one beam is incident on a region of the sample that is different from that of the other beam, the signals will differ in both amplitude and phase. This gives a resultant signal that is detected by the lock-in amplifier. If a sample with a homogeneous "standard"

(1) Now at the Department of Aeronautics and Astronautics, University of Southampton 
region, $\mathrm{A}$, and a region, $\mathrm{B}$, containing a thermal inhomogeneity is scanned, so that one beam is incident on $A$ and the other on $B$, the output signal will be zero except when the beam is traversing the inhomogeneity. This is the basis of the present differential imaging system.

\section{EXPERIMENTAL APPARATUS AND METHOD}

The experimental apparatus shown in Fig1 consists of an argon ion laser (Spectra-Physics 16408), a 50/50 plate type beam splitter (Melles Griot 03BTF011) and a 5 slot optical chopper wheel with a mark-space ratio of 1:1 (Stanford Research Systems SR540). After division the beams pass through diametrically opposite sides of the chopper and into the photoacoustic cell. The photoacoustic signal is amplified by a low noise amplifier (Brookdeal model 450) and detected by a lock-in amplifier (Stanford Research System SR530). Data from the lock-in amplifier is recorded by a computer interface (Stanford Research Systems SR245). The photoacoustic cell is mounted on an X-Y translation stage driven by a computerised micro-stepping controller (Aerotech model Unidex-11) which could be moved in $0.1 \mu \mathrm{m}$ steps over a total distance of $5 \mathrm{~cm}$.

In practice to obtain a $180^{\circ}$ phase difference one of the reflecting mirrors was adjusted using a micrometer. Equal intensities were produced by passing one of the beams through a variable neutral density filter. In setting up the system it was found convenient to have one of the beams more intense than the other. This gave a definite fixed frequency signal for the lock-in amplifier to lock on to. If the signals were exactly the same amplitude and $180^{\circ}$ out of phase the lock-in amplifier would try and follow the noise signal and oscillate wildly in signal and phase. Fine tuning of the beams was achieved by monitoring the output from the photoacoustic cell.

In order to test the sub-surface scanning capabilities of the system a sample was made which contained a standard region, A, and a region, B, which contained a sub-surface defect. A was a homogeneous piece of Metset, a polyester setting plastic, (Buehler, plc) and B was Metset in which was embedded a $1.8 \mathrm{~mm}$ diameter semi-cylindrical copper wire with the flat surface uppermost just below the surface. The upper surfaces of both A and B were coated with matt black silicon based paint (RS 496-782) to give maximum optical absorption.

\section{RESULTS}

Figs. 2 and 3 show the signal and phase respectively for scans across a sample with one beam on $\mathrm{A}$ and the other beam on $\mathrm{B}$, with the scan direction perpendicular to the wire. The upper graphs on each of the figures are conventional scans using only one pump beam, while the lower ones are differential scans using two beams. For both Fig.2 and 3 the modulation frequency was $270 \mathrm{~Hz}$ corresponding to a probe depth of $11 \mu \mathrm{m}$. The signal scans in Fig. 2 show two important features. The noise in the conventional scan is about $1 \times 10^{-5} \mathrm{mV}$ while that for the differential system is approximately $0.2 \times 10^{-5} \mathrm{mV}$. The signal in the conventional system drops to about $0.8 \times 10^{-4} \mathrm{mV}$ as the beam passes over the copper wire due to the relatively large thermal diffusivity of copper. The differential system shows an increase in signal of $1.8 \times 10^{-4} \mathrm{mV}$ above the noise level. This is due to the smaller amplitude thermal wave being phase shifted and giving constructive interference between the A and B signals resulting in an increased intensity.

The phase signal in Fig. 2 shows that the noise is reduced from $20^{\circ}$ in the conventional system to approximately $1^{\circ}$ in the differential system.

The present system has shown to have considerable advantages over conventional scanning systems. Further experiments on two dimensional scans are being carried out. 


\section{References}

[1] Wong Y.H. in Scanned Image Microscopy (1980) 247 Ed. E.A.Ash, Academic Press, London pp .247-271

[2] Busse G. and Rosencwaig A., (1980) Appl.Phys.Lett. 36 (10) 815.

[3] Teng X.M. and Inglehart L.J., in Photoacoustic and Photothermal Phenomena II, 37, Eds. Murphy J.C. et al. (1989), Springer-Verlag, Berlin.

[4] Wong Y.H., Thomas R.L. and Hawkins G.F., Appl.Phys Lett.(1978) 32538.

[5] Adarms M.J and Kirkbright G.F. (1977) Analyst 102, 678.

[6] Busse,G. and Ograbeck,A.,(1980) J.Appl.Phys. 51, 3576

[7] Quimby,R.S. (1981), Appl.Phys.Lett 39, 880-882

[8] Lehto,A.,Jokinen,M.,Jaarinen,J.,Tiusanen,T. and Luukkala,M.(1981) Electron.Lett.17,540-1

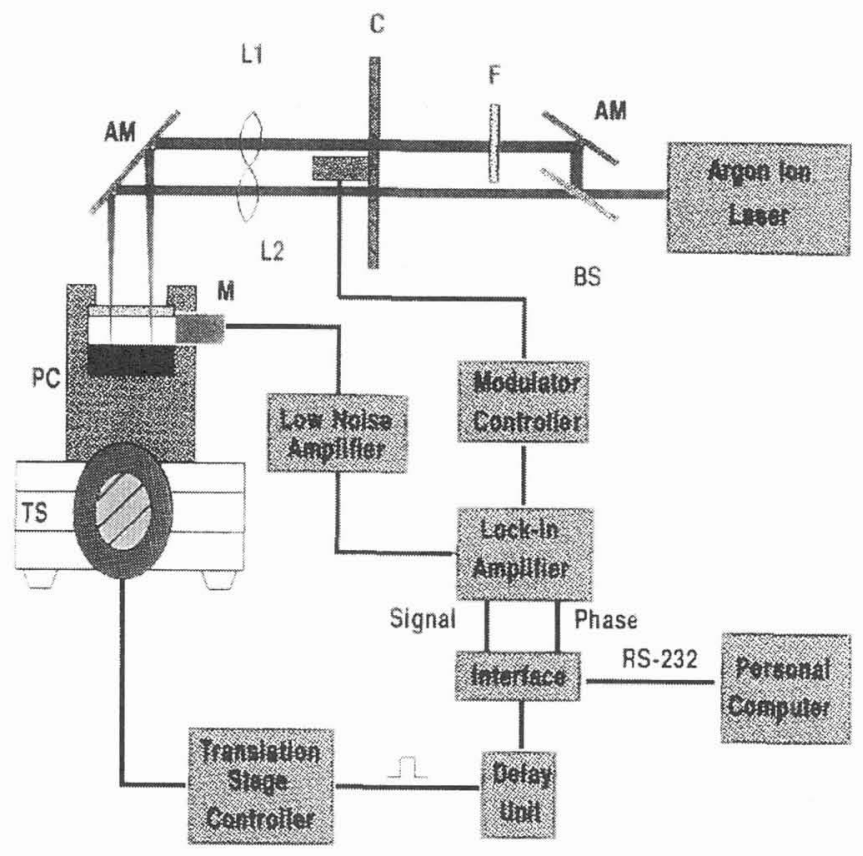

L1. CONVEX LENS

L2 - CONVEX LENS

Figure 1

C - 5.SLOT OPTICAL CHOPPER

AU - ADJUSTABLE MIRROR

F - VARIABLE NEUTRAL DENSITY FILTER

M. MICROPHONE

PC - PHOTOACOUSTIC CELL

BS - BEAM SPLITEE

TS - TRANSLATION STACE

A - 'STANDARD' SAMPLE

B - TEST' SAMPLE 
Comparison Between Differential and Non-Differential Scanning Sample - Copper Rod Embedded in Metset coated with Block Paint Sconning Frequency $=270 \mathrm{~Hz} \sim 11 \mu \mathrm{m}$

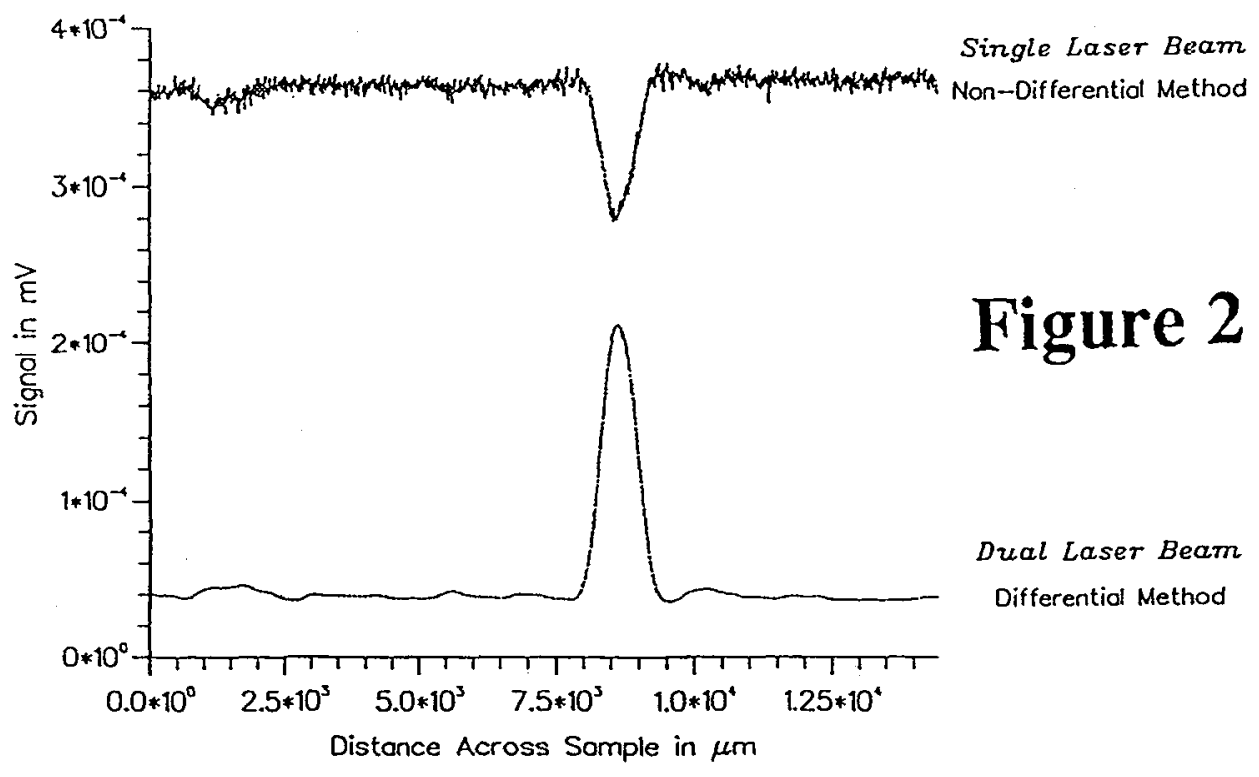

Comparison Between Differential and Non-Differential Scanning Somple - Copper Rod Embedded in Metset coated with Black Paint Sconning Frequency $=270 \mathrm{~Hz} \sim 11 \mu \mathrm{m}$

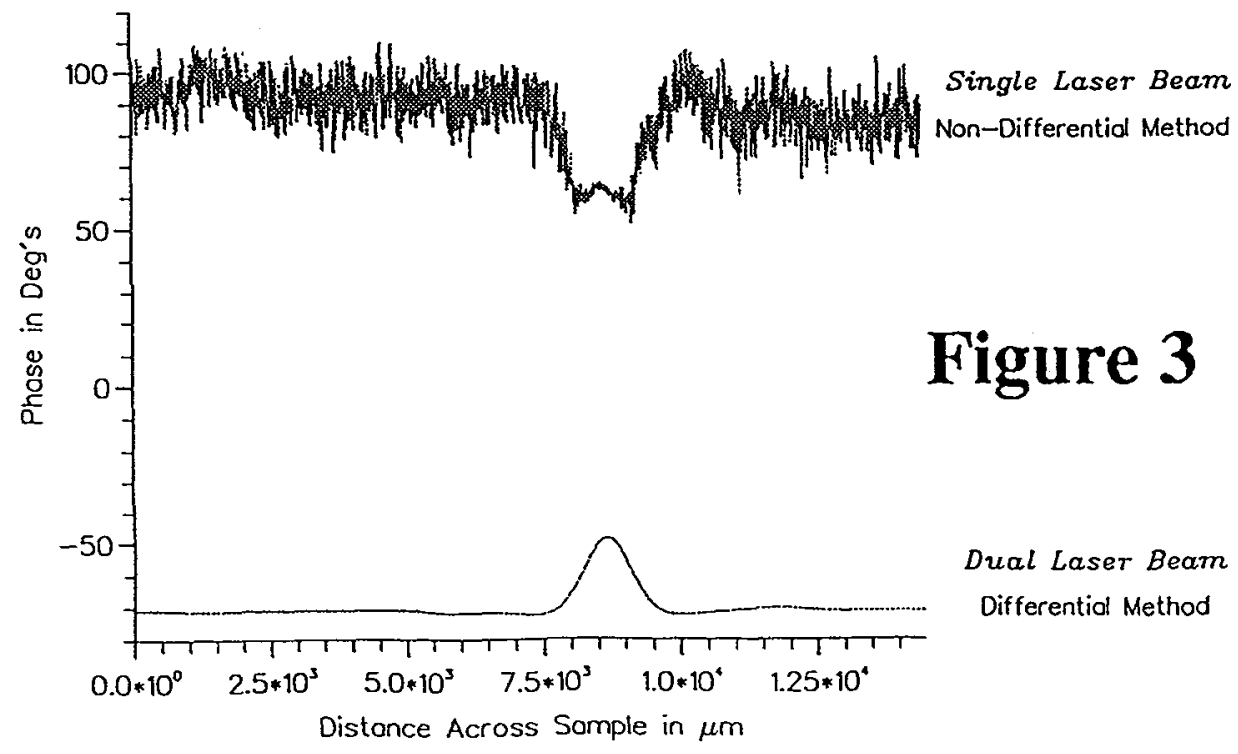

